\title{
Actions of Steroids: New Neurotransmitters
}

\author{
@Lauren M. Rudolph, ${ }^{1}{ }^{\circ}$ Charlotte A. Cornil, ${ }^{2}$ Melinda A. Mittelman-Smith, ${ }^{1}{ }^{\oplus}$ Jennifer R. Rainville, ${ }^{3}$ \\ Luke Remage-Healey, ${ }^{4}$-Kevin Sinchak, ${ }^{5}$ and ${ }^{-P}$ Paul E. Micevych ${ }^{1}$ \\ ${ }^{1}$ Department of Neurobiology and Laboratory of Neuroendocrinology, David Geffen School of Medicine at the University of California Los Angeles, Los \\ Angeles, California 90095, ${ }^{2}$ Behavioral Neuroendocrinology Group, GIGA Neurosciences, University of Liège, 4000 Liege, Belgium, ${ }^{3}$ Department of Cell and \\ Molecular Biology, Tulane University, New Orleans, Louisiana 70118, ${ }^{4}$ Department of Psychological and Brain Sciences, Center for Neuroendocrine Studies, \\ University of Massachusetts, Amherst, Massachusetts 01003, and 5Department of Biological Sciences, California State University, Long Beach, Long Beach, \\ California 90840
}

Over the past two decades, the classical understanding of steroid action has been updated to include rapid, membrane-initiated, neurotransmitter-like functions. While steroids were known to function on very short time spans to induce physiological and behavioral changes, the mechanisms by which these changes occur are now becoming more clear. In avian systems, rapid estradiol effects can be mediated via local alterations in aromatase activity, which precisely regulates the temporal and spatial availability of estrogens. Acute regulation of brain-derived estrogens has been shown to rapidly affect sensorimotor function and sexual motivation in birds. In rodents, estrogens and progesterone are critical for reproduction, including preovulatory events and female sexual receptivity. Membrane progesterone receptor as well as classical progesterone receptor trafficked to the membrane mediate reproductive-related hypothalamic physiology, via second messenger systems with dopamine-induced cell signals. In addition to these relatively rapid actions, estrogen membrane-initiated signaling elicits changes in morphology. In the arcuate nucleus of the hypothalamus, these changes are needed for lordosis behavior. Recent evidence also demonstrates that membrane glucocorticoid receptor is present in numerous cell types and species, including mammals. Further, membrane glucocorticoid receptor influences glucocorticoid receptor translocation to the nucleus effecting transcriptional activity. The studies presented here underscore the evidence that steroids behave like neurotransmitters to regulate CNS functions. In the future, we hope to fully characterize steroid receptor-specific functions in the brain.

\section{Introduction}

At one time, the actions of steroid hormones were thought to mediate physiological changes through changes in gene transcription over an extended time course. This incomplete picture of steroid action has been filled in by the additional understanding that these compounds can have rapid, extragenomic, membrane-initiated actions. It has been known for decades that steroid hormones can have acute actions (within minutes) on physiology (Szego and Davis, 1967), the activity of neurons (Kelly et al., 1976), and the expression of behavior (Hayden-Hixson and Ferris, 1991). More recently, data demonstrate that steroids can and do function in ways that are "neurotransmitter-like," as they are synthesized at precise spatial locations within neural circuits and can act within minutes as local neuromodulators to rapidly regulate cognitive functions and behaviors (Balthazart and Ball,

Received Aug. 3, 2016; revised Aug. 30, 2016; accepted Sept. 9, 2016.

This work was supported by National Institutes of Health R01HD058638, Arnold and Mabel Beckman Foundation, Howell-CSUPERB Research Scholars Awards, and National Science Foundation Grant HRD-1302873 LSAMP to K.S., National Institutes of Health R01/MH50388, BELSPO-SSTC PAI P7/17 (Belgian Interuniversity Attraction Poles), FRS-FNRS PDR T.00.15, FRS-FNRS CDR J.0101.13, and FSRC-14/40 (Special Fund for Research University of Liege) to C.A.C., National Institutes of Health R01 NS082179 and National Science Foundation IOS 1354906 to L.R.-H., HD042635 and DA013185 to P.E.M., and HD07228 to L.M.R.

The authors declare no competing financial interests.

Correspondence should be addressed to Dr. Lauren M. Rudolph, University of California Los Angeles Department of Neurobiology, CHS 63-170, 650 Charles E. Young Drive South, Los Angeles, CA 90095. E-mail: Irudolph@mednet.ucla.edu.

DOI:10.1523/JNEUROSCI.2473-16.2016

Copyright $\odot 2016$ the authors $\quad 0270-6474 / 16 / 3611449-10 \$ 15.00 / 0$
2006; Dewing et al., 2007; Saldanha et al., 2011; Remage-Healey, 2014). Here we discuss the ever-growing body of evidence detailing nonclassical, neurotransmitter-like steroid hormone action across neural systems, species, and classes of steroids, and suggest that these compounds should also be considered neurotransmitters, as they regularly function independently of classical hormone signaling in an increasing number of systems and species.

\section{Neurotransmitter-like effects of steroids \\ Estrogens in birds}

An important update to the classical view of steroid function involved our understanding of how and where steroids could be produced. Historically, it was accepted that steroids were synthesized in peripheral endocrine organs and traveled great distances to exert physiological effects at target tissues. We have known that neurosteroid production occurs in rodents for some time (e.g., for review, see Baulieu, 1991) and now understand that estrogens can be synthesized centrally, by neurons, both in their cell somata and at discrete synaptic junctions in birds as well (Naftolin et al., 1996; Saldanha et al., 2000; Peterson et al., 2005).

In vitro work in quail hypothalamus/preoptic area followed by in vivo studies in behaving zebra finches demonstrated that brain estrogen synthesis is acutely controlled within neurons and driven by changes in neuronal activity (Balthazart et al., 2001, 2006; Remage-Healey et al., 2008) via acute regulation of brain aromatase activity by calcium-dependent phosphorylation (Balthazart et al., 2001, 2003; Charlier et al., 2011; Cornil et al., 

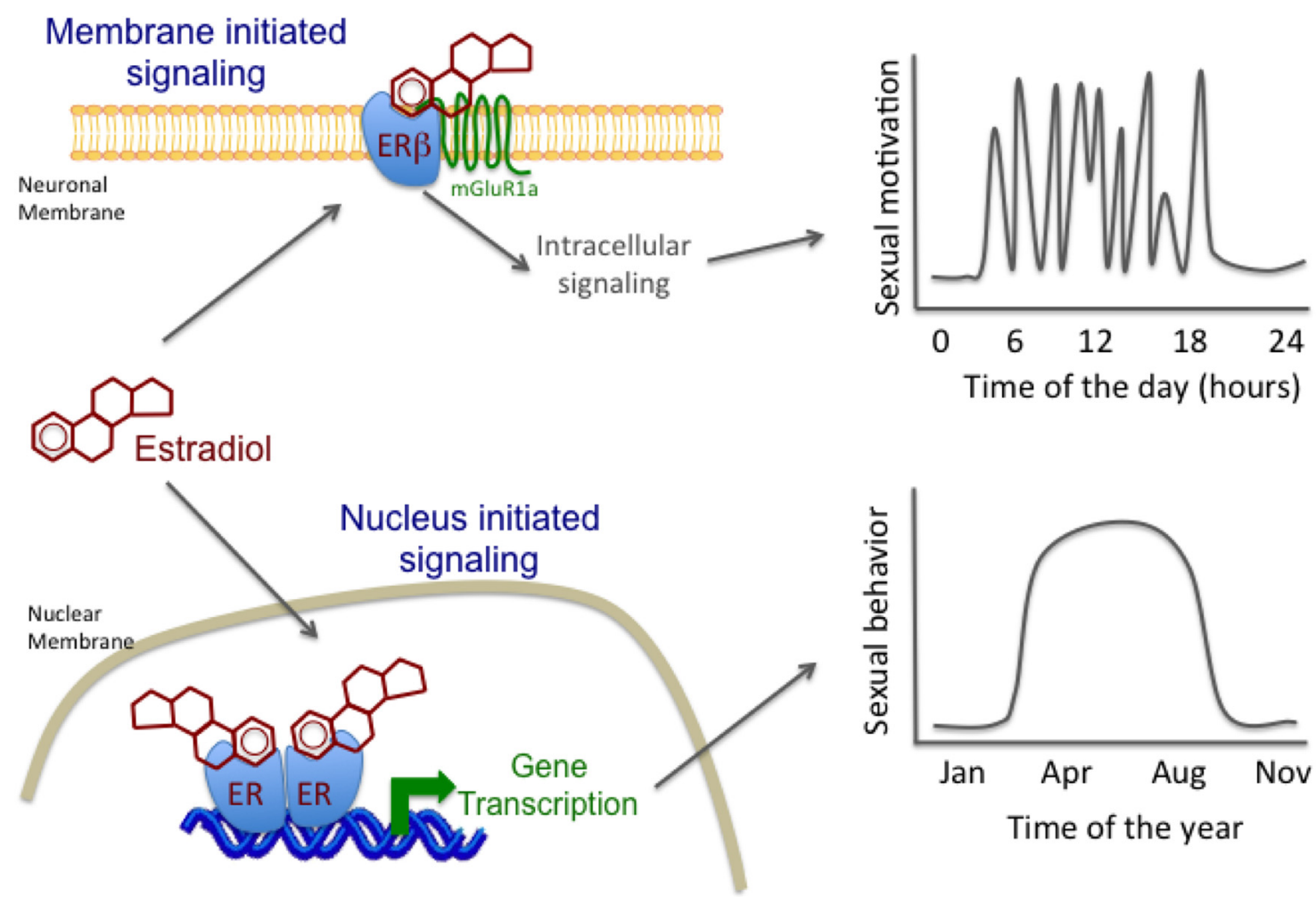

Figure 1. Schematic representation of the dual action of estrogen hypothesis for the regulation of male sexual behavior. The nuclear-initiated effects of brain estrogens associated with long-term changes in gonadal testosterone secretion would activate the circuits underlying the expression of sexual behavior, while membrane-initiated effects would, in a manner similar to neuromodulators, acutely (within $15 \mathrm{~min}$ ) modulate these primed circuits and determine whether animals engage in this behavior at a specific moment. These two complementary modes of action of the same chemical messenger would thus cooperate to regulate the long- and short-term aspect of the same behavior.

2012b; Comito et al., 2015). Interestingly, this acute regulation of brain estrogen production can occur specifically at presynaptic terminals, providing very fine spatial and temporal control over estrogen availability (Remage-Healey et al., 2011; Cornil et al., 2012b). This fine regulation of estradiol synthesis appears to be driven by the activity of aromatase. The aromatase enzyme uses androgens (typically testosterone) as precursors. Increasing evidence indicates that, particularly in the songbird, the concentration of brain androgens is acutely modulated through the regulation of their local synthesis (Pradhan et al., 2010; Heimovics et al., 2016). However, a rapid and reversible reduction in aromatase activity, paralleled by a change in estradiol brain concentration, was measured ex vivo in whole or specific hypothalamus/preoptic area subregions collected immediately after visual or sexual interactions with a female (Cornil et al., 2005; de Bournonville et al., 2013; Dickens et al., 2014), suggesting that aromatase activity is the critical component that determines estradiol availability. aromatase activity is upregulated in distinct brain regions following brief exposure to acute stress (Dickens et al., 2011), an effect that is counteracted by sexual interaction (Dickens et al., 2012). Therefore, brain aromatase activity is also rapidly and dynamically regulated in vivo in a region- and context-dependent manner and in a way that affects behavior. Changes in behaviors could thus result from rapid changes in local brain estrogen production, presumably at the synaptic level.

In addition to the mechanisms of synthesis, the time scale of estrogen action also approximates that of neurotransmitters. Estrogens produced by brain aromatization of testosterone play a pivotal role in the activation of male sexual behavior in birds and mammals (Balthazart et al., 2004; Hull and Rodriguez-Manzo,
2009). The effects of estrogens on behavior are typically associated with long-term changes in circulating levels of testosterone and are therefore mainly considered to result from the transcriptional activity of their nuclear receptors (McEwen and Alves, 1999). According to this view, the long-term effects of brainderived estrogens (neuroestrogens) would prime the neural circuits involved in the regulation of behavior, which would then be acutely modulated by neurotransmitter systems conveying information from the environment (e.g., presence of a sexual partner or predator; Fig. 1). The discovery that neuroestrogens are also able to produce much faster effects at the cellular level than previously anticipated (Maggi et al., 2004; Vasudevan and Pfaff, 2007) and that their synthesis can be acutely regulated in the brains of avian species (Remage-Healey et al., 2008; Charlier et al., 2015) prompted further research on the short-term regulation of behavior by brain-derived estrogens. Although it is now clear that neuroestrogens acutely influence numerous physiological or behavioral processes in birds, many advances on the rapid effects of estrogens on behavior have been obtained in the study of male sexual behavior and auditory processing (Cornil et al., 2012a; Krentzel and Remage-Healey, 2015).

Initial studies investigating the acute effect of estradiol administered systemically found that estradiol facilitates sexual behavior within 10-35 min, whereas systemic aromatase inhibition impairs this behavior within 10-30 min depending on the species (Cross and Roselli, 1999; Cornil et al., 2006a, b; Taziaux et al., 2007). Direct manipulations of brain estrogen synthesis or action subsequently showed that estradiol produces short lived $(<2 \mathrm{~h})$ and estrogen receptor- $\beta$ (ER $\beta)$-dependent membrane-initiated effects through the transactivation of metabotropic glutamate receptor 1 (Seredynski et al., 2013, 2015) as demonstrated in 
rodents (for review, see Micevych and Mermelstein, 2008). Importantly, this work identified an interesting dichotomy in the regulation of male sexual behavior by membrane- and nuclearinitiated signaling of estrogens. Specifically, acute membraneinitiated effects control sexual motivation (Seredynski et al., 2013,2015 ), whereas the priming of the neuronal circuits controlling the performance of coordinated motor sequences depends exclusively on a long-term exposure to both testosterone and their aromatized metabolites, estrogens (Seredynski et al., 2013; Niessen et al., 2011).

Further evidence that estrogens act more similar to neurotransmitters than "classical" steroids is due to the fact that the rapid effects of estrogen are not limited to female reproduction. Indeed, they occur in both sexes in a variety of behavioral contexts, notably auditory processing in birds (Krentzel and Remage-Healey, 2015). Studies using in vivo microdialysis have documented that brain-derived estrogens can fluctuate dynamically in sensorimotor circuits of adult songbirds (Remage-Healey et al., 2008; Remage-Healey et al., 2012) as well as juvenile songbirds (Chao et al., 2015), in a variety of socially relevant contexts. In addition, it appears that rapid estrogen signaling occurs in male and female birds alike, further supporting the idea that estrogens are neurotransmitter-like and not just female reproductive hormones (Remage-Healey, 2014). Local estrogen signaling within discrete circuits has consequences for neuronal activity and for circuit-relevant behaviors. In songbirds, estrogens rapidly enhance the encoding of auditory stimuli in individual forebrain neurons (Tremere et al., 2009; Remage-Healey et al., 2010, 2012), whereas blocking local estrogen synthesis can impair auditory encoding. Together, this survey of recent work shows that brain-derived estrogens can influence neural circuit function and behavior via a time course and mechanism similar to traditional neurotransmitters.

Collectively, these data support the idea that, in birds, some aspects of acute behavioral regulation depend not only on classical neurotransmitter systems, but also on acute and spatially restricted changes in local estrogen availability (Balthazart and Ball, 2006; Saldanha et al., 2011). There is a growing literature indicating that the acute regulation by estrogens on phenomena, such as sexual motivation, is generalizable to other systems and behavioral circuits (Cornil et al., 2015). For example, in both songbirds (Remage-Healey et al., 2010; Bailey et al., 2013) and mice (Tuscher et al., 2016), local infusion of estrogen synthesis blockers in the auditory forebrain and hippocampus impairs complex behaviors, such as sensory processing and spatial memory, respectively (see also Bailey and Saldanha, 2015).

In vivo microdialysis has been adapted in an increasing number of species and relevant brain areas to examine local fluctuations in estrogens. From this recent evidence, it is now clear that rapid estrogen signaling plays a key role in hypothalamic feedback in rhesus monkeys (Kenealy et al., 2013), seizure proliferation in the rat hippocampus (Sato and Woolley, 2016), and gonadotropin feedback in quail preoptic area (Ubuka et al., 2014). As this technique is applied to other species and systems, we will begin to better understand the prevalence and specifics of neurotransmitter-like effects of estrogens underlying a variety of behaviors in a wide range of systems and species. On the other end of the estrogen signaling input-output relationship, the mechanism that can account for the fast cessation of estrogen signaling is still unknown. Estrogen signaling in neural circuits could be temporally and spatially restrained via mechanisms that include degradation, diffusion, packaging, conjugation, or other "stop-signals" similar to conventional neurotransmitters. It is likely, therefore, that local estrogen synthesis in the brain is important for a variety of other behaviors; this possibility has been implicated, but not yet directly tested, in several recent reports (Ervin et al., 2015; Lamm et al., 2015; Phan et al., 2015; Murakami, 2016).

\section{Estrogens, progesterone, and reproductive events in rodents}

Steroids, such as progesterone, have been shown to have rapid neurotransmitter-like effects that rapidly change the activity of neuronal systems through multiple types of receptors (for review, see Micevych and Mermelstein, 2008; Mani and Oyola, 2012; Sinchak and Wagner, 2012; Micevych et al., 2015; ValadezCosmes et al., 2016). Some of these steroid receptors that initiate rapid signaling are, as expected, classified as extranuclear or membrane receptors, which signal through G-proteins or other second messenger systems (Zhou et al., 1996; Razandi et al., 1999; Boulware et al., 2005; Zuloaga et al., 2012; Valadez-Cosmes et al., 2016). However, a relatively recent finding shows that classical steroid receptors that are classified as transcription factors and bind to response elements on the DNA to regulate gene expression also contain palmitoylation sequences that allow them to be trafficked to the plasma membrane to rapidly alter cellular activity (Boulware et al., 2007; Pedram et al., 2007; Meitzen et al., 2013; for review, see Micevych and Mermelstein, 2008; Grove-Strawser et al., 2010; Mani et al., 2012; Schwartz et al., 2016). These nuclear transcription factors are trafficked to the plasma membrane and require direct interactions with other proteins to initiate their signaling at the level of the plasma membrane (Boonyaratanakornkit et al., 2001, 2007; Micevych and Mermelstein, 2008; Boulware and Mermelstein, 2009). From here, intracellular signaling cascades involving effectors (e.g., MAPK) are initiated via the transactivation of cell surface-bound receptors, most notably metabotropic glutamate receptors (mGluRs). Estrogen membrane-initiated signaling (EMS) can also lead to subsequent activation of CREB to affect transcription. Similarly, progesterone can activate classical progesterone receptor (PR) at the plasma membrane, which appears to transactivate Src kinase (Src).

Before its characterization in bird sexual motivation, mGluRmediated, membrane-initiated steroid signaling was shown to be a key component of the preovulatory events in rodent reproduction. Rising levels of estradiol on proestrus excite circuits that activate gonadotropin-releasing hormone $(\mathrm{GnRH})$ neurons, which signal gonadotrophs in the pituitary to release luteinizing hormone (LH) that induces ovulation. Removal of the influence of ovarian steroids prevents the LH surge. Replacement of estradiol will restore the surge; however, this effect is magnified by additional replacement with progesterone. Estradiol appears to work "upstream" of progesterone signaling by upregulating PR in the anterior hypothalamus (Simerly et al., 1996; Shughrue et al., 1997) and facilitating local progesterone synthesis in hypothalamic astrocytes (Sinchak et al., 2003; Ogi et al., 2004; Micevych et al., 2007). While the specific molecular pathways through which estradiol and progesterone signaling are integrated have not been characterized, both estrogen receptor $\alpha$ $(\mathrm{ER} \alpha)$ and PR are needed (Ogawa et al., 1996; Conneely et al., 2002; Stephens et al., 2015). Further, the dominant ER in reproduction is $\mathrm{ER} \alpha$. Indeed, mice genetically lacking $\operatorname{ER} \alpha$ do not exhibit proper estradiol positive or negative feedback on LH; (Dorling et al., 2003; Wintermantel et al., 2006; but see Dubois et al., 2015) and do not display sexually receptive behavior (Rissman et al., 1997). Similarly, classical PR is critical to reproduction: knock-outs or pharmacological blockade of the receptor 
lead to infertility and inability to properly mount an LH surge (Chappell and Levine, 2000). Recently, the critical site of PR expression has been localized to kisspeptin (kiss1) neurons of the anterior hypothalamus (Stephens et al., 2015; Gal et al., 2016). Anterior hypothalamic kiss1 neurons are the principal stimulators of GnRH neurons (e.g., Han et al., 2005). Indeed, the lack of expression of $\mathrm{ER} \alpha$ and $\mathrm{PR}$ in $\mathrm{GnRH}$ neurons indicates that another population expressing these classical receptors mediates estrogen-positive feedback on LH release. Kiss1 neurons express $\mathrm{ER} \alpha$ and estradiol-induced PR (Zhang et al., 2014) and have been considered critical site for this feedback based on their induction by estradiol (Clarkson and Herbison, 2009; Brock and Bakker, 2013; Smith, 2013).

Currently, it is hypothesized that activation of membrane PR in kiss1 neurons underlies progesterone augmentation of estradiol positive feedback on LH release. The role of cell membranelocalized PR on circuits governing the LH surge has been investigated using the immortalized cell line, mHypoA51. These cells were originally isolated from adult, female mouse hypothalamus and appear to recapitulate anterior hypothalamic kiss 1 neurons in vivo. In mHypoA51 cells, EMS is needed for kiss1 upregulation, whereas classical, nuclear ER $\alpha$ activation mediates upregulation of PR (Mittelman-Smith et al., 2015). PR is observed on the membrane of these cells and mediates activation of rapid intracellular kinases, such as Src and Erk1/2 (MittelmanSmith et al., under revision). Treatment with progesterone augmented estradiol-induced kiss1 protein levels, which may have implications for estradiol and progesterone integration in kiss 1 neurons in vivo, that stimulate GnRH neurons to elicit the $\mathrm{LH}$ surge.

Nonclassical progesterone action also mediates sexual receptivity in rodents. Progesterone receptor-B (PR-B) is a classical transcription factor, but progesterone has been shown to have rapid neurotransmitter-like actions through PR-B to facilitate sexual receptivity (Mani et al., 1994; Serey et al., 2014b). Rapid actions of PR-B signaling are involved in a subcircuit regulating lordosis, which originates in the arcuate nucleus of the hypothalamus (ARH) and projects to the medial preoptic nucleus (MPN) (for review, see Sinchak and Wagner, 2012; Sinchak et al., 2015). To initiate rapid signaling at the level of the plasma membrane, PR-B complexes with and signals through Src (Boonyaratanakornkit et al., 2001, 2007; Phan et al., 2014). Infusion of progesterone into the ARH of estradiol-primed ovariectomized rats facilitates receptivity within $30 \mathrm{~min}$ by inhibiting $\mathrm{ARH}$ $\beta$-endorphin neurons that project to the MPN, which induces sexual receptivity (Huss et al., 2011). These rapid actions of progesterone are mediated by extranuclear PR-B that complex with and signal through Src. This PR-B-Src signaling is also dependent on dopamine receptor D1/D5 (D1/D5). The PR-B, D1/D5, and Src signaling pathways that facilitate sexual receptivity converge in the ARH and appear to be interdependent. Antagonizing one blocks facilitation of lordosis by the other two (Serey et al., 2014a). It is hypothesized that these PR-B-Src-D1/D5 interactions occur in ARH $\beta$-endorphin neurons. Indeed, double-label immunohistochemistry in ARH tissue from estradiol-primed female rats demonstrated PR and D1 colocalization in the ARH, which is increased following estradiol treatment (Sinchak et al., 2014). Subpopulations of ARH $\beta$-endorphin neurons coexpress PR and D1 (Phan et al., 2015). Together, these results indicate the potential for ARH $\beta$-endorphin neurons to be the point of PR-B and D1/D5 signaling convergence that facilitates sexual receptivity. However, although PR-B, Src, D1, and D5 were present in ARH membrane and cytosolic fractions, coimmunoprecipitation revealed D1 and D5 did not complex with either PR or Src on the plasma membrane (Phan et al., 2015, 2016). Thus, it is likely that the cross talk is further downstream within the cell signaling cascade, such as through G-protein subunits activated by D1/D5 interacting with, and regulating, the rapid actions of progesterone signaling through PR-B-Src complexes.

In addition to its regulation by progesterone, sexual receptivity is induced by estradiol. Similar to the progesterone regulation of the circuit modulating lordosis, estradiol controls lordosis via nonclassical, neurotransmitter-like actions. The ARH-MPNVMH "lordosis circuit" is sensitive to changes in estradiol and undergoes morphological alterations in dendritic structures in order for the display of female sexual receptivity (Matsumoto and Arai, 1986). Nonclassical estradiol signaling is the initial step of estradiol action in this circuit and triggers signaling that is responsible for spinogenesis in the ARH, and ultimately successful reproduction (Christensen et al., 2011). The primary step of estradiol signaling in the ARH occurs via $\mathrm{ER} \alpha$ transactivation of mGluRla in NPY neurons of the ARH. In vitro, the trafficking and internalization of $\operatorname{ER} \alpha$ are regulated by $\beta$-arrestin and involve the ERK1/2 pathway, which initiates morphological changes that are coincident with and required for the display of lordosis behavior (Wong et al., 2015a). Within 4 h of estradiol treatment, immature, filopodia-like dendritic spines are formed in the ARH (Christensen et al., 2011). At $24 \mathrm{~h}$ after estradiol treatment, there is a shift in the proportion of dendritic spines, with a decrease in filopodia and concomitant increase in mature, mushroomshaped spines (Christensen et al., 2011). The formation of new spines is necessary for the estradiol-induced lordosis, as blocking spine formation significantly reduces the expression of sexual receptivity (Christensen et al., 2011).

Spinogenesis is initiated by estradiol action at membrane ER $\alpha$ (Fig. 2), and the mechanisms responsible for spine maturation are currently being investigated. Within an hour of estradiol treatment, cofilin is phosphorylated, allowing for its deactivation, which is required for the generation of new spines to occur (Christensen et al., 2011) (Fig. 2). Recent evidence indicates that spine formation is coregulated by presynaptic and postsynaptic components, as GAP43 and PSD-95 mRNA are induced along a similar timeline following estradiol treatment in vivo (Wong et al., 2015b). The induction of these presynaptic and postsynaptic markers is blocked by mGluRla antagonists, suggesting that EMS mediates both the presynaptic and postsynaptic elements of synaptogenesis that underlies lordosis behavior (Wong et al., 2015b). Another component of the ARH-MPN-VMH circuit required for lordosis behavior is activation/internalization of $\mu$ opioid receptor (MOR) in the MPN. This process produces a transient inhibition of the circuit that is required for its subsequent activation, and is controlled by EMS. Merely 20 min after estradiol treatment, MOR is activated and internalized in the MPN via a process that occurs along a time scale approximating neurotransmitterlike activity (Mills et al., 2004). This MOR internalization is induced using membrane-impermeable estradiol (Dewing et al., 2007) and occurs through a PKC $\theta$ pathway (Dewing et al., 2008), further implicating the neurotransmitter-like signaling characteristics of steroids.

Classical steroid receptors are involved in the hypothalamic circuitry regulating rodent reproduction, and these receptors signal via both classical (e.g., nuclear) and nonclassical (e.g., membrane-localized) mechanisms. The membrane-initiated effects of ER $\alpha$ and PR signaling are critical for the LH surge and female sexual receptivity. As future studies determine the local mechanisms by which these pathways are regulated, we will con- 


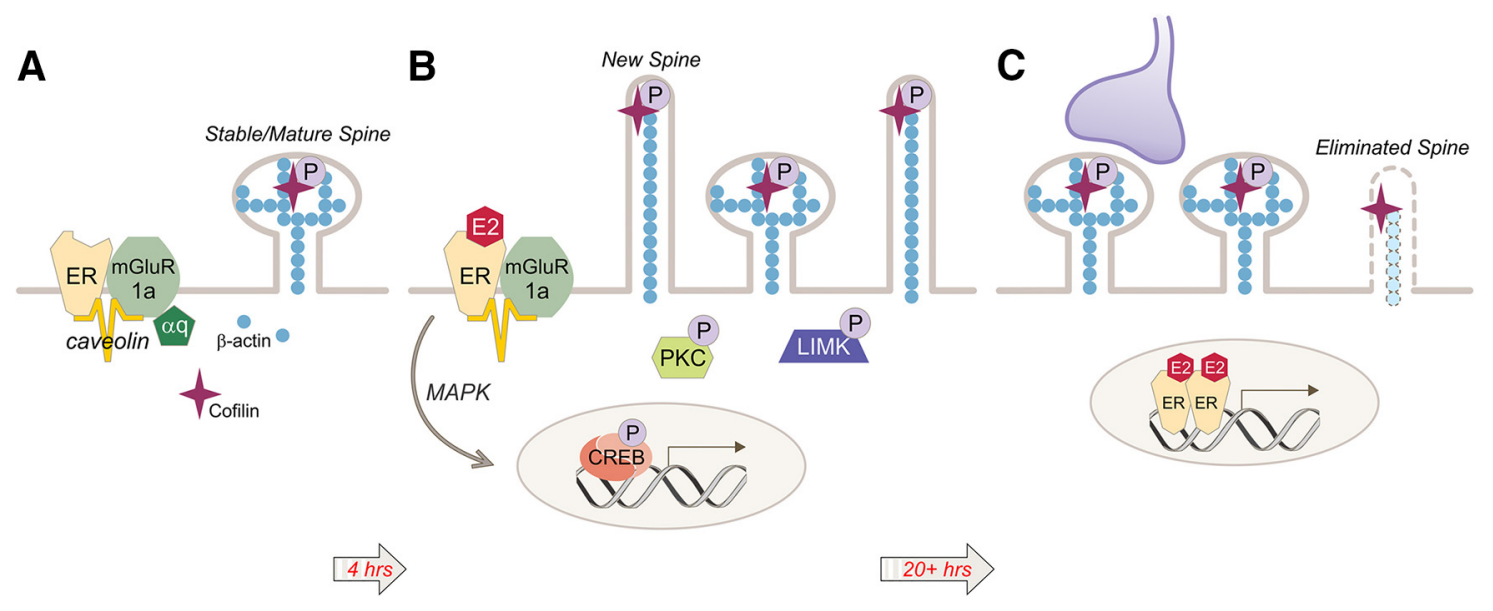

Figure 2. EMS induces dendritic spine formation in the ARH. $\boldsymbol{A}$, During low estradiol conditions (e.g., diestrus), ARH neurons have a population of mature spines. $\boldsymbol{B}$, Estradiol stimulates the ER $\alpha$-mGluR1a signaling complex, leading to activation of PKC and LIM kinase (LIMK) and the phosphorylation of cofilin. This deactivation of cofilin allows for the formation of immature, filopodial spines. EMS stimulates gene expression through the activation of the MAPK pathway leading to CREB-mediated transcription. C, Spine maturation results in mushroom-shaped spines that are thought to be functional and stable. The time course of spine maturation coincides with the display of lordosis behavior in the female rat, beginning $20 \mathrm{~h}$ after estradiol treatment. Spine maturation is regulated by either gene transcription resulting from membrane to nucleus signaling $(\boldsymbol{B})$ or direct nuclear action $(\boldsymbol{C})$.

tinue to update our understanding of the breadth and depth of neurotransmitter-like steroid signaling and its role in reproductive events.

\section{Glucocorticoid signaling}

Although most evidence of neurotransmitter-like actions of steroids has focused on estrogens and progesterone and reproduction, other steroids have also been shown to act via nonclassical mechanisms. Glucocorticoids are a class of steroid hormones that act via the glucocorticoid receptor (GR), a nuclear receptor (Aranda and Pascual, 2001) that is localized in the cytoplasm bound to chaperone proteins. Classical GR signaling requires ligand binding to initiate GR dimerization and translocation to the nucleus (Oakley and Cidlowski, 2013) where it interacts directly with DNA and other transcription factors to regulate gene transcription. Post-translational modifications of the GR (e.g., phosphorylation) can alter the transcriptional effects of GR activation (Kumar and Calhoun, 2008), providing a potential link between cell signaling pathways and GR-mediated transcriptional activity.

As with estrogens and progestins, glucocorticoids can act at the membrane to alter physiology, functioning more like neurotransmitters than classical steroid hormones. The enzymes required for corticosterone synthesis are present throughout the brain (MacKenzie et al., 2000), and de novo corticosterone synthesis from pregnenolone has been detected in the hippocampus of adrenalectomized rats (Higo et al., 2011). Various lines of evidence suggest that glucocorticoids have membrane as well as intracellular actions. Radiolabeled glucocorticoid binding has been documented in membrane fractions of amphibian brain (Orchinik et al., 1991; Evans et al., 2000) and the rodent hypothalamus (Nahar et al., 2016). Further, GR immunolabeling has been demonstrated in neuronal membranes of the rat hypothalamus, hippocampus, and amygdala (Liposits and Bohn, 1993; Johnson et al., 2005) and in human lymphocytes and leukocytes (Bartholome et al., 2004). Stably transfected siRNA to GR $\alpha$ decreased the expression of membrane glucocorticoid receptor (mGR) in CD14 ${ }^{+}$monocytes (Strehl et al., 2011), and conditional knockdown of GR in the mouse hypothalamus abolished the rapid, membrane-initiated glucocorticoid effects in neuroen- docrine cells (Nahar et al., 2015; Nahar et al., 2016), suggesting that GR and mGR may originate from the same gene.

In addition to the morphological evidence for membrane localization of the intracellular GR, activation of G-proteincoupled cascades has been observed following membranelimited glucocorticoid treatment and is responsible for rapid effects in rat hippocampal primary culture (Yang et al., 2013) and rat and mouse hypothalamic slices (Di et al., 2005; MalcherLopes et al., 2006; Di et al., 2009; Nahar et al., 2015). Studies in primary hippocampal neurons and in hypothalamic slices revealed rapid activation of kinase pathways in response to BSAconjugated glucocorticoids, which signal only at the cell membrane (Qi et al., 2005; Malcher-Lopes et al., 2006; Yang et al., 2013). Similar kinase pathway activation has been reported in the absence of detectable GR, suggesting the presence of a novel mGR that signals via G-protein and protein kinase pathways (Xiao et al., 2005).

Significantly, many of the kinases implicated in rapid glucocorticoid actions have also been shown to phosphorylate GR and influence transcriptional activity (Galliher-Beckley and Cidlowski, 2009). p38 MAPK activity may increase GR transcriptional activation at the glucocorticoid response element (GRE) in cancer cell lines through GR phosphorylation at serine 211 (Miller et al., 2005; Chen et al., 2008). In rat cortical neuron primary cultures, the orthologous phosphorylation site, S232, renders GR less transcriptionally active (Kino et al., 2007), suggesting that GR phosphorylation has cell type-specific effects (Galliher-Beckley et al., 2011). GR phosphorylation at S134 (Galliher-Beckley et al., 2011; Piovan et al., 2013), S203 (Bouazza et al., 2014), and S226 (Chen et al., 2008) also has transcriptional effects. Collectively, these studies support a model of integrated signaling that couples signal transduction cascades to GRmediated transcription (Kumar and Calhoun, 2008), which may be as important for GR physiology as it is for estrogen physiology (Clark et al., 2014).

GR phosphorylation also affects nuclear trafficking of the receptor. Phosphorylation at S203 restricted GR to the cytoplasm in cancer cells following treatment with dexamethasone (Wang et al., 2002). Transfection with the phosphorylation-resistant mu- 
tant GR S203A resulted in increased GR nuclear localization and GRE-mediated transcription (Bouazza et al., 2014). In a human hippocampal cell line, the kinase, SGK-1, increased GR phosphorylation at S203 and S211, facilitating nuclear localization of the unliganded receptor (Anacker et al., 2013). Nuclear translocation of the unliganded GR in mammary gland cells results in activation of apoptotic pathways, and has effects opposite those of liganded GR, which induces growth and differentiation (Ritter and Mueller, 2014). These data present the possibility that a balance of transcriptional activity between liganded and unliganded GR in the nucleus may influence the net cellular response to glucocorticoids. Preliminary data from a hypothalamic neuronal cell line indicate that both dexamethasone and dexamethasoneBSA rapidly induce GR nuclear localization in a hypothalamic neuronal cell line, suggesting that trafficking to the nucleus does not require a ligand-bound GR. Importantly, the unliganded GR failed to stimulate transcriptional activity at the GRE, corroborating observations from HEK 293T cells (Strehl et al., 2011). Therefore, rapid, membrane-initiated glucocorticoid signaling directly regulates trafficking of the intracellular GR, with the potential for specific effects on GR-mediated transcriptional regulation depending on whether the receptor is liganded or unliganded. Future studies should assess the role of mGR in neuronal function across systems and species, and will likely demonstrate that these and other neurotransmitter-like effects of GR signaling are common and critical to neuronal physiology and behavior (Di et al., 2016).

\section{Discussion}

These various studies all demonstrate that the era of "simple" direct nuclear actions of steroids is over. Both so-called gonadal and adrenal steroids have now been demonstrated to signal at the membrane as well as the nucleus to regulate brain function. Importantly, when steroid signaling is initiated at the membrane, intracellular signaling cascades are activated that can regulate transcription. Thus, transcriptional regulation remains a vital part of steroid signaling. The experiments reviewed here have begun to fill in the missing pieces of how and where the steroid signals are initiated. In earlier times, steroid receptors were considered to be strict ligand-gated transcription factors (Gronemeyer and Laudet, 1995) that acted at specific stretches of DNA, the response elements. Canonical response elements were described for ER, the estrogen response elements, for progesterone, the progesterone response elements, and the GREs for glucocorticoids (for review, see Beato et al., 1996). Although this was an elegant hypothesis, the response elements were seen to have problems almost from the beginning. In some cases, partial elements appeared to be as active as the full-length response element. In other cases, for example, the liganded and dimerized ER could also stabilize Sp1 and AP-1 sites (Paech et al., 1997; Webb et al., 1999; Safe and Kim, 2004; Panno et al., 2006). Although these were forms of direct nuclear actions, they already suggested that ER actions were heterogeneous. In parallel, several groups reported rapid actions (i.e., within minutes) of steroid hormones, especially in the brain (Szego and Davis, 1967; Kelly et al., 1976; Lagrange et al., 1996; Mermelstein et al., 1996). Together, all these results implied that our understanding of steroid action was incomplete.

The fullness of steroid actions in the brain and their complexity have been more recently demonstrated by results pointing to membrane-initiated signaling. These experiments forced a paradigm shift: no longer were steroids restricted to the "slow" signaling associated with transcription and translation of new proteins.
Now cellular responses to steroids in the nervous system have been shown to be on the same time-frame as GPCRs that influence a variety of cellular functions: gating membrane channels (e.g., voltage-gated calcium channels), increasing intracellular calcium release, activating Src, MAPK, or phosphatidylinositol3-kinase-AKT pathways, which eventually phosphorylate CREB protein. An interesting phenomenon of membrane-initiate signaling is that steroid receptors interact with other GPCRs or growth factor receptors, for example, with mGluRs, and insulin growth factor-1 (Quesada and Etgen, 2002; Micevych and Mermelstein, 2008). In reproduction, a variety of membraneinitiated estrogen actions are due to direct transactivation of mGluRs (Micevych and Mermelstein, 2008).

In this review, we have discussed actions of steroids a number of which are synthesized both peripherally and in the CNS. We have argued that neurosteroids may be more properly considered neurotransmitters based on their site and regulation of synthesis, and cellular actions. Neurosteroids, like endocannabinoids, nitric oxide, and prostaglandins, are neurotransmitters whose extracellular levels are regulated at the point of synthesis (Micevych and Sinchak, 2008) and which can occur at synaptic terminals (Saldanha et al., 2011). Once synthesized, these messengers are released or, more correctly, diffuse out the cell to bind both membrane and intracellular receptors. The membrane receptors for steroids, once activated, follow similar dynamics as other neurotransmitter receptors (Hammes and Levin, 2007). Following natural ligand binding, membrane receptors are phosphorylated and internalized. This process limits the duration of membraneinitiated signaling. This has best been studied for ER, but the mechanisms are likely to be conserved for membrane PR and GR.

For some steroids, their membrane-initiated actions have been demonstrated throughout the CNS. For others evidence of region-specific function or the global extent this signaling mechanism is not as complete as for membrane-initiated estrogen signaling. On the other hand, the cell signaling mechanisms for ER, $\mathrm{PR}$, and GR have all been well characterized. The results presented here point to the importance of their roles in physiological processes controlled by the CNS, and to the complexity of steroid signaling.

Part of this complexity is reflected in the plethora of putative steroid receptors that have been identified. In addition to various isoforms, a number of splice variants of classical intracellular receptors have been characterized. For example, for estrogen there are $\operatorname{ER} \alpha$ and $\operatorname{ER} \beta$ isoforms, as well as a number of splice variants (e.g., $\mathrm{ER} \alpha \Delta 4$ ) that can initiate signaling from the membrane (Micevych and Mermelstein, 2008; Dominguez et al., 2013). Additionally, GPR30 is an ER that is a GPCR; and although there is controversy over whether GPR30 is present on the cell membrane, there is no question that this receptor is involved in estrogen signaling in the brain (Kuo et al., 2010; Hammond et al., 2011; Long et al., 2014). In another case, we only have pharmacological evidence for a putative ER that is activated by STX (Micevych and Kelly, 2012). For progesterone, the classic nuclear PR has been localized to the membrane and a whole new class of PRs, the membrane PRs, have been found that appear to be involved in the reproductive actions of progesterone (Zuloaga et al., 2012; Mittelman-Smith et al., 2015, in revision). For glucocorticoids, there is mounting evidence that, in addition to the classical GR, another, as yet uncharacterized receptor mediates membrane-initiated signaling.

For some, the apparent variety of membrane steroid receptors and putative receptors reflects a chaotic situation that magnifies a lack of understanding of membrane-initiated steroid signaling. 
But rather than being anomalous, this appears to be the norm with respect to membrane receptors. For example, there are at least five dopamine receptor subtypes (Cools and Van Rossum, 1976; Ellenbroek et al., 2014) and the glutamate receptors are divided into metabotropic receptors, with 3 groups each with several subtypes (Swanson et al., 2005), and 3 families of ionotropic receptors, again with several subtypes (Dingledine et al., 1999; Andersson et al., 2001). The challenge for us is to determine the functionality of the diversity of membrane steroid receptors.

\section{References}

Anacker C, Cattaneo A, Musaelyan K, Zunszain PA, Horowitz M, Molteni R, Luoni A, Calabrese F, Tansey K, Gennarelli M, Thuret S, Price J, Uher R, Riva MA, Pariante CM (2013) Role for the kinase SGK1 in stress, depression, and glucocorticoid effects on hippocampal neurogenesis. Proc Natl Acad Sci U S A 110:8708-8713. CrossRef Medline

Andersson O, Stenqvist A, Attersand A, von Euler G (2001) Nucleotide sequence, genomic organization, and chromosomal localization of genes encoding the human NMDA receptor subunits NR3A and NR3B. Genomics 78:178-184. CrossRef Medline

Aranda A, Pascual A (2001) Nuclear hormone receptors and gene expression. Physiol Rev 81:1269-1304. Medline

Bailey DJ, Saldanha CJ (2015) The importance of neural aromatization in the acquisition, recall, and integration of song and spatial memories in passerines. Horm Behav 74:116-124. CrossRef Medline

Bailey DJ, Ma C, Soma KK, Saldanha CJ (2013) Inhibition of hippocampal aromatization impairs spatial memory performance in a male songbird. Endocrinology 154:4707-4714. CrossRef Medline

Balthazart J, Ball GF (2006) Is brain estradiol a hormone or a neurotransmitter? Trends Neurosci 29:241-249. CrossRef Medline

Balthazart J, Baillien M, Ball GF (2001) Rapid and reversible inhibition of brain aromatase activity. J Neuroendocrinol 13:63-73. CrossRef Medline

Balthazart J, Baillien M, Charlier TD, Ball GF (2003) Calcium-dependent phosphorylation processes control brain aromatase in quail. Eur J Neurosci 17:1591-1606. CrossRef Medline

Balthazart J, Baillien M, Cornil CA, Ball GF (2004) Preoptic aromatase modulates male sexual behavior: slow and fast mechanisms of action. Physiol Behav 83:247-270. CrossRef Medline

Balthazart J, Baillien M, Ball GF (2006) Rapid control of brain aromatase activity by glutamatergic inputs. Endocrinology 147:359-366. CrossRef Medline

Bartholome B, Spies CM, Gaber T, Schuchmann S, Berki T, Kunkel D, Bienert M, Radbruch A, Burmester GR, Lauster R, Scheffold A, Buttgereit F (2004) Membrane glucocorticoid receptors (mGCR) are expressed in normal human peripheral blood mononuclear cells and up-regulated after in vitro stimulation and in patients with rheumatoid arthritis. FASEB J 18:70-80. CrossRef Medline

Baulieu EE (1991) Neurosteroids: a new function in the brain. Biol Cell 71:3-10. CrossRef Medline

Beato M, Truss M, Chavez S (1996) Control of transcription by steroid hormones. Ann N Y Acad Sci 784:93-123. CrossRef Medline

Boonyaratanakornkit V, Scott MP, Ribon V, Sherman L, Anderson SM, Maller JL, Miller WT, Edwards DP (2001) Progesterone receptor contains a proline-rich motif that directly interacts with $\mathrm{SH} 3$ domains and activates c-Src family tyrosine kinases. Mol Cell 8:269-280. CrossRef Medline

Boonyaratanakornkit V, McGowan E, Sherman L, Mancini MA, Cheskis BJ, Edwards DP (2007) The role of extranuclear signaling actions of progesterone receptor in mediating progesterone regulation of gene expression and the cell cycle. Mol Endocrinol 21:359-375. CrossRef Medline

Bouazza B, Debba-Pavard M, Amrani Y, Isaacs L, O'Connell D, Ahamed S, Formella D, Tliba O (2014) Basal p38 mitogen-activated protein kinase regulates unliganded glucocorticoid receptor function in airway smooth muscle cells. Am J Respir Cell Mol Biol 50:301-315. CrossRef Medline

Boulware MI, Mermelstein PG (2009) Membrane estrogen receptors activate metabotropic glutamate receptors to influence nervous system physiology. Steroids 74:608-613. CrossRef Medline

Boulware MI, Weick JP, Becklund BR, Kuo SP, Groth RD, Mermelstein PG (2005) Estradiol activates group I and II metabotropic glutamate receptor signaling, leading to opposing influences on cAMP response elementbinding protein. J Neurosci 25:5066-5078. CrossRef Medline
Boulware MI, Kordasiewicz H, Mermelstein PG (2007) Caveolin proteins are essential for distinct effects of membrane estrogen receptors in neurons. J Neurosci 27:9941-9950. CrossRef Medline

Brock O, Bakker J (2013) The two kisspeptin neuronal populations are differentially organized and activated by estradiol in mice. Endocrinology 154:2739-2749. CrossRef Medline

Chao A, Paon A, Remage-Healey L (2015) Dynamic variation in forebrain estradiol levels during song learning. Dev Neurobiol 75:271-286. CrossRef Medline

Chappell PE, Levine JE (2000) Stimulation of gonadotropin-releasing hormone surges by estrogen: I. Role of hypothalamic progesterone receptors. Endocrinology 141:1477-1485. CrossRef Medline

Charlier TD, Harada N, Balthazart J, Cornil CA (2011) Human and quail aromatase activity is rapidly and reversibly inhibited by phosphorylating conditions. Endocrinology 152:4199-4210. CrossRef Medline

Charlier TD, Cornil CA, Patte-Mensah C, Meyer L, Mensah-Nyagan AG, Balthazart J (2015) Local modulation of steroid action: rapid control of enzymatic activity. Front Neurosci 9:83. CrossRef Medline

Chen W, Dang T, Blind RD, Wang Z, Cavasotto CN, Hittelman AB, Rogatsky I, Logan SK, Garabedian MJ (2008) Glucocorticoid receptor phosphorylation differentially affects target gene expression. Mol Endocrinol 22: 1754-1766. CrossRef Medline

Christensen A, Dewing P, Micevych P (2011) Membrane-initiated estradiol signaling induces spinogenesis required for female sexual receptivity. J Neurosci 31:17583-17589. CrossRef Medline

Clark S, Rainville J, Zhao X, Katzenellenbogen BS, Pfaff D, Vasudevan N (2014) Estrogen receptor-mediated transcription involves the activation of multiple kinase pathways in neuroblastoma cells. J Steroid Biochem Mol Biol 139:45-53. CrossRef Medline

Clarkson J, Herbison AE (2009) Oestrogen, kisspeptin, GPR54 and the preovulatory luteinising hormone surge. J Neuroendocrinol 21:305-311. CrossRef Medline

Comito D, Pradhan DS, Karleen BJ, Schlinger BA (2015) Region-specific rapid regulation of aromatase activity in zebra finch brain. J Neurochem. Advance online publication. Retrieved Dec. 28, 2015. doi: 10.1111/ jnc.13513. CrossRef Medline

Conneely OM, Mulac-Jericevic B, DeMayo F, Lydon JP, O’Malley BW (2002) Reproductive functions of progesterone receptors. Recent Prog Horm Res 57:339-355. CrossRef Medline

Cools AR, Van Rossum JM (1976) Excitation-mediating and inhibitionmediating dopamine-receptors: a new concept towards a better understanding of electrophysiological, biochemical, pharmacological, functional and clinical data. Psychopharmacologia 45:243-254. CrossRef Medline

Cornil CA, Dalla C, Papadopoulou-Daifoti Z, Baillien M, Dejace C, Ball GF, Balthazart J (2005) Sexual behavior affects preoptic aromatase activity and brain monoamines' levels. Endocrinology 146:3809-3820. CrossRef Medline

Cornil CA, Taziaux M, Baillien M, Ball GF, Balthazart J (2006a) Rapid effects of aromatase inhibition on male reproductive behaviors in Japanese quail. Horm Behav 49:45-67. CrossRef Medline

Cornil CA, Dalla C, Papadopoulou-Daifoti Z, Baillien M, Balthazart J (2006b) Estradiol rapidly activates male sexual behavior and affects brain monoamine levels in the quail brain. Behav Brain Res 66:110-123. CrossRef Medline

Cornil CA, Ball GF, Balthazart J (2012a) Rapid control of male typical behaviors by brain-derived estrogens. Front Neuroendocrinol 33:425-446. CrossRef Medline

Cornil CA, Leung CH, Pletcher ER, Naranjo KC, Blauman SJ, Saldanha CJ (2012b) Acute and specific modulation of presynaptic aromatization in the vertebrate brain. Endocrinology 153:2562-2567. CrossRef Medline

Cornil CA, Ball GF, Balthazart J (2015) The dual action of estrogen hypothesis. Trends Neurosci 38:408-416. CrossRef Medline

Cross E, Roselli CE (1999) 17 $\beta$-Estradiol rapidly facilitates chemoinvestigation and mounting in castrated male rats. Am J Physiol 276:R1346R1350. Medline

de Bournonville C, Dickens MJ, Ball GF, Balthazart J, Cornil CA (2013) Dynamic changes in brain aromatase activity following sexual interactions in males: where, when and why? Psychoneuroendocrinology 38: 789-799. CrossRef Medline

Dewing P, Boulware MI, Sinchak K, Christensen A, Mermelstein PG, Micevych P (2007) Membrane estrogen receptor-alpha interactions 
with metabotropic glutamate receptor 1a modulate female sexual receptivity in rats. J Neurosci 27:9294-9300. CrossRef Medline

Dewing P, Christensen A, Bondar G, Micevych P (2008) Protein kinase C signaling in the hypothalamic arcuate nucleus regulates sexual receptivity in female rats. Endocrinology 149:5934-5942. CrossRef Medline

Di S, Malcher-Lopes R, Marcheselli VL, Bazan NG, Tasker JG (2005) Rapid glucocorticoid-mediated endocannabinoid release and opposing regulation of glutamate and gamma-aminobutyric acid inputs to hypothalamic magnocellular neurons. Endocrinology 146:4292-4301. CrossRef Medline

Di S, Maxson MM, Franco A, Tasker JG (2009) Glucocorticoids regulate glutamate and GABA synapse-specific retrograde transmission via divergent nongenomic signaling pathways. J Neurosci 29:393-401. CrossRef Medline

Di S, Itoga CA, Fisher MO, Solomonow J, Roltsch EA, Gilpin NW, Tasker JG (2016) Acute stress suppresses synaptic inhibition and increases anxiety via endocannabinoid release in the basolateral amygdala. J Neurosci 36: 8461-8470. CrossRef Medline

Dickens MJ, Cornil CA, Balthazart J (2011) Acute stress differentially affects aromatase activity in specific brain nuclei of adult male and female quail. Endocrinology 152:4242-4251. CrossRef Medline

Dickens MJ, Balthazart J, Cornil CA (2012) Brain aromatase and circulating corticosterone are rapidly regulated by combined acute stress and sexual interaction in a sex-specific manner. J Neuroendocrinol 24:1322-1334. CrossRef Medline

Dickens MJ, de Bournonville C, Balthazart J, Cornil CA (2014) Relationships between rapid changes in local aromatase activity and estradiol concentrations in male and female quail brain. Horm Behav 65:154-164. CrossRef Medline

Dingledine R, Borges K, Bowie D, Traynelis SF (1999) The glutamate receptor ion channels. Pharmacol Rev 51:7-61. Medline

Dominguez R, Dewing P, Kuo J, Micevych P (2013) Membrane-initiated estradiol signaling in immortalized hypothalamic N-38 neurons. Steroids 78:607-613. CrossRef Medline

Dorling AA, Todman MG, Korach KS, Herbison AE (2003) Critical role for estrogen receptor alpha in negative feedback regulation of gonadotropinreleasing hormone mRNA expression in the female mouse. Neuroendocrinology 78:204-209. CrossRef Medline

Dubois SL, Acosta-Martínez M, DeJoseph MR, Wolfe A, Radovick S, Boehm U, Urban JH, Levine JE (2015) Positive, but not negative feedback actions of estradiol in adult female mice require estrogen receptor alpha in kisspeptin neurons. Endocrinology 156:1111-1120. CrossRef Medline

Ellenbroek BA, Homberg J, Verheij M, Spooren W, van den Bos R, Martens G (2014) Alexander Rudolf Cools (1942-2013). Psychopharmacology (Berl) 231:2219-2222. CrossRef Medline

Ervin KS, Lymer JM, Matta R, Clipperton-Allen AE, Kavaliers M, Choleris E (2015) Estrogen involvement in social behavior in rodents: rapid and long-term actions. Horm Behav 74:53-76. CrossRef Medline

Evans SJ, Murray TF, Moore FL (2000) Partial purification and biochemical characterization of a membrane glucocorticoid receptor from an amphibian brain. J Steroid Biochem Mol Biol 72:209-221. CrossRef Medline

Gal A, Lin PC, Cacioppo JA, Hannon PR, Mahoney MM, Wolfe A, Fernandez-Valdivia R, Lydon JP, Elias CF, Ko C (2016) Loss of fertility in the absence of progesterone receptor expression in kisspeptin neurons of female mice. PLoS One 11:e0159534. CrossRef Medline

Galliher-Beckley AJ, Cidlowski JA (2009) Emerging roles of glucocorticoid receptor phosphorylation in modulating glucocorticoid hormone action in health and disease. IUBMB Life 61:979-986. CrossRef Medline

Galliher-Beckley AJ, Williams JG, Cidlowski JA (2011) Ligand-independent phosphorylation of the glucocorticoid receptor integrates cellular stress pathways with nuclear receptor signaling. Mol Cell Biol 31:4663-4675. CrossRef Medline

Gronemeyer H, Laudet V (1995) Transcription factors 3: nuclear receptors. Protein Profile 2:1173-1308. Medline

Grove-Strawser D, Boulware MI, Mermelstein PG (2010) Membrane estrogen receptors activate the metabotropic glutamate receptors mGluR5 and mGluR3 to bidirectionally regulate CREB phosphorylation in female rat striatal neurons. Neuroscience 170:1045-1055. CrossRef Medline
Hammes SR, Levin ER (2007) Extranuclear steroid receptors: nature and actions. Endocr Rev 28:726-741. CrossRef Medline

Hammond R, Nelson D, Gibbs RB (2011) GPR30 co-localizes with cholinergic neurons in the basal forebrain and enhances potassium-stimulated acetylcholine release in the hippocampus. Psychoneuroendocrinology 36: 182-192. CrossRef Medline

Han SK, Gottsch ML, Lee KJ, Popa SM, Smith JT, Jakawich SK, Clifton DK, Steiner RA, Herbison AE (2005) Activation of gonadotropin-releasing hormone neurons by kisspeptin as a neuroendocrine switch for the onset of puberty. J Neurosci 25:11349-11356. CrossRef Medline

Hayden-Hixson DM, Ferris CF (1991) Steroid-specific regulation of agonistic responding in the anterior hypothalamus of male hamsters. Physiol Behav 50:793-799. CrossRef Medline

Heimovics SA, Prior NH, Ma C, Soma KK (2016) Rapid effects of an aggressive interaction on dehydroepiandrosterone, testosterone and oestradiol levels in the male song sparrow brain: a seasonal comparison. J Neuroendocrinol 28:12345. CrossRef Medline

Higo S, Hojo Y, Ishii H, Komatsuzaki Y, Ooishi Y, Murakami G, Mukai H, Yamazaki T, Nakahara D, Barron A, Kimoto T, Kawato S (2011) Endogenous synthesis of corticosteroids in the hippocampus. PLoS One 6:e21631. CrossRef Medline

Hull EM, Rodriguez-Manzo G (2009) Male sexual behavior. In: Hormones, brain and behavior (Pfaff DW, Arnold AP, Etgen AM, Fahrbach SE, Rubin RT, eds), pp 5-65. San Diego: Academic.

Huss B, Long NP, Ponce L, Gomez L, Moore CA, Sinchak K (2011) Progesterone rapidly facilitates sexual receptivity through deactivation of muopioid receptors in the medial preoptic nucleus of the hypothalamus. In: Society for Neuroscience, Program 391.307, Abstract Viewer/Itinerary Planner, Washington, DC.

Johnson LR, Farb C, Morrison JH, McEwen BS, LeDoux JE (2005) Localization of glucocorticoid receptors at postsynaptic membranes in the lateral amygdala. Neuroscience 136:289-299. CrossRef Medline

Kelly MJ, Moss RL, Dudley CA (1976) Differential sensitivity of preopticseptal neurons to microelectrophoresed estrogen during the estrous cycle. Brain Res 114:152-157. CrossRef Medline

Kenealy BP, Kapoor A, Guerriero KA, Keen KL, Garcia JP, Kurian JR, Ziegler TE, Terasawa E (2013) Neuroestradiol in the hypothalamus contributes to the regulation of gonadotropin releasing hormone release. J Neurosci 33:19051-19059. CrossRef Medline

Kino T, Ichijo T, Amin ND, Kesavapany S, Wang Y, Kim N, Rao S, Player A, Zheng YL, Garabedian MJ, Kawasaki E, Pant HC, Chrousos GP (2007) Cyclin-dependent kinase 5 differentially regulates the transcriptional activity of the glucocorticoid receptor through phosphorylation: clinical implications for the nervous system response to glucocorticoids and stress. Mol Endocrinol 21:1552-1568. CrossRef Medline

Krentzel AA, Remage-Healey L (2015) Sex differences and rapid estrogen signaling: a look at songbird audition. Front Neuroendocrinol 38:37-49. CrossRef Medline

Kumar R, Calhoun WJ (2008) Differential regulation of the transcriptional activity of the glucocorticoid receptor through site-specific phosphorylation. Biologics 2:845-854. Medline

Kuo J, Hamid N, Bondar G, Prossnitz ER, Micevych P (2010) Membrane estrogen receptors stimulate intracellular calcium release and progesterone synthesis in hypothalamic astrocytes. J Neurosci 30:12950-12957. CrossRef Medline

Lagrange AH, Wagner EJ, Rønnekleiv OK, Kelly MJ (1996) Estrogen rapidly attenuates a GABAB response in hypothalamic neurons. Neuroendocrinology 64:114-123. Medline

Lamm MS, Liu H, Gemmell NJ, Godwin JR (2015) The need for speed: neuroendocrine regulation of socially-controlled sex change. Integr Comp Biol 55:307-322. CrossRef Medline

Liposits Z, Bohn MC (1993) Association of glucocorticoid receptor immunoreactivity with cell membrane and transport vesicles in hippocampal and hypothalamuc neurons of the rat. J Neurosci Res 35:14-19. CrossRef Medline

Long N, Serey C, Sinchak K (2014) 17 $\beta$-estradiol rapidly facilitates lordosis through G protein-coupled estrogen receptor 1 (GPER) via deactivation of medial preoptic nucleus $\mu$-opioid receptors in estradiol primed female rats. Horm Behav 66:663-666. CrossRef Medline

MacKenzie SM, Clark CJ, Ingram MC, Lai M, Seckl J, Gomez-Sanchez CE, Fraser R, Connell JM, Davies E (2000) Corticosteroid production by fetal rat hippocampal neurons. Endocr Res 26:531-535. CrossRef Medline 
Maggi A, Ciana P, Belcredito S, Vegeto E (2004) Estrogens in the nervous system: mechanisms and nonreproductive functions. Annu Rev Physiol 66:291-313. CrossRef Medline

Malcher-Lopes R, Di S, Marcheselli VS, Weng FJ, Stuart CT, Bazan NG, Tasker JG (2006) Opposing crosstalk between leptin and glucocorticoids rapidly modulates synaptic excitation via endocannabinoid release. J Neurosci 26:6643-6650. CrossRef Medline

Mani SK, Oyola MG (2012) Progesterone signaling mechanisms in brain and behavior. Front Endocrinol (Lausanne) 3:7. CrossRef Medline

Mani SK, Blaustein JD, Allen JM, Law SW, O’Malley BW, Clark JH (1994) Inhibition of rat sexual behavior by antisense oligonucleotides to the progesterone receptor. Endocrinology 135:1409-1414. CrossRef Medline

Mani SK, Mermelstein PG, Tetel MJ, Anesetti G (2012) Convergence of multiple mechanisms of steroid hormone action. Horm Metab Res 44: 569-576. CrossRef Medline

Matsumoto A, Arai Y (1986) Development of sexual dimorphism in synaptic organization in the ventromedial nucleus of the hypothlamus in rats. Neurosci Lett 68:165-168. CrossRef Medline

McEwen BS, Alves SE (1999) Estrogen actions in the central nervous system. Endocr Rev 20:279-307. CrossRef Medline

Meitzen J, Luoma JI, Boulware MI, Hedges VL, Peterson BM, Tuomela K, Britson KA, Mermelstein PG (2013) Palmitoylation of estrogen receptors is essential for neuronal membrane signaling. Endocrinology 154: 4293-4304. CrossRef Medline

Mermelstein PG, Becker JB, Surmeier DJ (1996) Estradiol reduces calcium currents in rat neostriatal neurons via a membrane receptor. J Neurosci 16:595-604. Medline

Micevych P, Sinchak K (2008) Estradiol regulation of progesterone synthesis in the brain. Mol Cell Endocrinol 290:44-50. CrossRef Medline

Micevych PE, Kelly MJ (2012) Membrane estrogen receptor regulation of hypothalamic function. Neuroendocrinology 96:103-110. CrossRef Medline

Micevych PE, Mermelstein PG (2008) Membrane estrogen receptors acting through metabotropic glutamate receptors: an emerging mechanism of estrogen action in brain. Mol Neurobiol 38:66-77. CrossRef Medline

Micevych PE, Chaban V, Ogi J, Dewing P, Lu JK, Sinchak K (2007) Estradiol stimulates progesterone synthesis in hypothalamic astrocyte cultures. Endocrinology 148:782-789. CrossRef Medline

Micevych PE, Wong AM, Mittelman-Smith MA (2015) Estradiol membraneinitiated signaling and female reproduction. Compr Physiol 5:1211-1222. CrossRef Medline

Miller AL, Webb MS, Copik AJ, Wang Y, Johnson BH, Kumar R, Thompson EB (2005) p38 mitogen-activated protein kinase (MAPK) is a key mediator in glucocorticoid-induced apoptosis of lymphoid cells: correlation between p38 MAPK activation and site-specific phosphorylation of the human glucocorticoid receptor at serine 211. Mol Endocrinol 19:15691583. CrossRef Medline

Mills RH, Sohn RK, Micevych PE (2004) Estrogen-induced $\mu$-opioid receptor internalization in the medial preoptic nucleus is mediated via neuropeptide Y-Y1 receptor activation in the arcuate nucleus of female rats. J Neurosci 24:947-955. CrossRef Medline

Mittelman-Smith MA, Wong AM, Kathiresan AS, Micevych PE (2015) Classical and membrane-initiated estrogen signaling in an in vitro model of anterior hypothalamic kisspeptin neurons. Endocrinology 156:21622173. CrossRef Medline

Murakami G (2016) Distinct effects of estrogen on mouse maternal behavior: the contribution of estrogen synthesis in the brain. PLoS One 11: e0150728. CrossRef Medline

Naftolin F, Horvath TL, Jakab RL, Leranth C, Harada N, Balthazart J (1996) Aromatase immunoreactivity in axon terminals of the vertebrate brain: an immunocytochemical study on quail, rat, monkey and human tissues. Neuroendocrinology 63:149-155. Medline

Nahar J, Haam J, Chen C, Jiang Z, Glatzer NR, Muglia LJ, Dohanich GP, Herman JP, Tasker JG (2015) Rapid nongenomic glucocorticoid actions in male mouse hypothalamic neuroendocrine cells are dependent on the nuclear glucocorticoid receptor. Endocrinology 156:2831-2842. CrossRef Medline

Nahar J, Rainville JR, Dohanich GP, Tasker JG (2016) Further evidence for a membrane receptor that binds glucocorticoids in the rodent hypothalamus. Steroid. Advance online publication. Retrieved Jun. 18, 2016. doi: 10.1016/j.steroids.2016.05.013. CrossRef Medline

Niessen NA, Balthazart J, Ball GF, Charlier TD (2011) Steroid receptor co- activator 2 modulates steroid-dependent male sexual behavior and neuroplasticity in Japanese quail (Coturnix japonica). J Neurochem 119:579_ 953. CrossRef Medline

Oakley RH, Cidlowski JA (2013) The biology of the glucocorticoid receptor: new signaling mechanisms in health and disease. J Allergy Clin Immunol 132:1033-1044. CrossRef Medline

Ogawa S, Taylor JA, Lubahn DB, Korach KS, Pfaff DW (1996) Reversal of sex roles in genetic female mice by disruption of estrogen receptor gene. Neuroendocrinology 64:467-470. Medline

Ogi J, Sinchak K, Soma KK, Lu JK, Micevych P (2004) Estrogen induces progesterone synthesis in hypothalamic astrocytes through an increase of intracellular calcium levels. In: Society for Neuroscience, Abstract Viewer/Itinerary Planner, Program 886.887, Washington, DC.

Orchinik M, Murray TF, Moore FL (1991) A corticosteroid receptor in neuronal membranes. Science 252:1848-1851. CrossRef Medline

Paech K, Webb P, Kuiper GG, Nilsson S, Gustafsson J, Kushner PJ, Scanlan TS (1997) Differential ligand activation of estrogen receptors ERalpha and ERbeta at AP1 sites. Science 277:1508-1510. CrossRef Medline

Panno ML, Mauro L, Marsico S, Bellizzi D, Rizza P, Morelli C, Salerno M, Giordano F, Andò S (2006) Evidence that the mouse insulin receptor substrate- 1 belongs to the gene family on which the promoter is activated by estrogen receptor alpha through its interaction with Sp1. J Mol Endocrinol 36:91-105. CrossRef Medline

Pedram A, Razandi M, Sainson RC, Kim JK, Hughes CC, Levin ER (2007) A conserved mechanism for steroid receptor translocation to the plasma membrane. J Biol Chem 282:22278-22288. CrossRef Medline

Peterson RS, Yarram L, Schlinger BA, Saldanha CJ (2005) Aromatase is presynaptic and sexually dimorphic in the adult zebra finch brain. Proc R Soc B Biol Sci 272:2089-2096. CrossRef Medline

Phan J, Mahavongtrakul M, Sinchak K (2014) Progesterone receptor-B and Src kinase complex in the plasma membrane of the arcuate nucleus of the hypothalamus of female rats. In: Society for Neuroscience, Neuroscience Meeting Planner, Program 167.110, Washington, DC.

Phan J, Le D, Choun T, Sinchak K (2015) Protein-protein interactions underlie the interdependence of progesterone receptor-B, dopamine D1 receptor and Src family kinase signaling in the plasma membrane of the arcuate nucleus of the hypothalamus of female rats. In: Society for Neuroscience, Neuroscience Meeting Planner, Program 715.712, Chicago.

Phan J, Rodman J, Sinchak K (2016) Dopamine receptor D1 and D5 do not form physical complexes with Src kinase on the plasma membrane to mediate actions of progesterone signaling in the arcuate nucleus of hypothalamus. In: Society for Neuroscience, Neuroscience Meeting Planner, San Diego.

Piovan E, Yu J, Tosello V, Herranz D, Ambesi-Impiombato A, Da Silva AC, Sanchez-Martin M, Perez-Garcia A, Rigo I, Castillo M, Indraccolo S, Cross JR, de Stanchina E, Paietta E, Racevskis J, Rowe JM, Tallman MS, Basso G, Meijerink JP, Cordon-Cardo C, et al. (2013) Direct reversal of glucocorticoid resistance by AKT inhibition in acute lymphoblastic leukemia. Cancer Cell 24:766-776. CrossRef Medline

Pradhan DS, Lau LY, Schmidt KL, Soma KK (2010) $3 \beta$-HSD in songbird brain: subcellular localization and rapid regulation by estradiol. J Neurochem 115:667-675. CrossRef Medline

Qi AQ, Qiu J, Xiao L, Chen YZ (2005) Rapid activation of JNK and p38 by glucocorticoids in primary cultured hippocampal cells. J Neurosci Res 80:510-517. CrossRef Medline

Quesada A, Etgen AM (2002) Functional interactions between estrogen and insulin-like growth factor-I in the regulation of alpha 1B-adrenoceptors and female reproductive function. J Neurosci 22:2401-2408. Medline

Razandi M, Pedram A, Greene GL, Levin ER (1999) Cell membrane and nuclear estrogen receptors (ERs) originate from a single transcript: studies of ERalpha and ERbeta expressed in Chinese hamster ovary cells. Mol Endocrinol 13:307-319. CrossRef Medline

Remage-Healey L (2014) Frank Beach Award Winner: steroids as neuromodulators of brain circuits and behavior. Horm Behav 66:552-560. CrossRef Medline

Remage-Healey L, Maidment NT, Schlinger BA (2008) Forebrain steroid levels fluctuate rapidly during social interactions. Nat Neurosci 11:13271334. CrossRef Medline

Remage-Healey L, Coleman MJ, Oyama RK, Schlinger BA (2010) Brain estrogens rapidly strengthen auditory encoding and guide song preference in a songbird. Proc Natl Acad Sci U S A 107:3852-3857. CrossRef Medline 
Remage-Healey L, Dong S, Maidment NT, Schlinger BA (2011) Presynaptic control of rapid estrogen fluctuations in the songbird auditory forebrain. J Neurosci 31:10034-10038. CrossRef Medline

Remage-Healey L, Dong SM, Chao A, Schlinger BA (2012) Sex-specific, rapid neuroestrogen fluctuations and neurophysiological actions in the songbird auditory forebrain. J Neurophysiol 107:1621-1631. CrossRef Medline

Rissman EF, Wersinger SR, Taylor JA, Lubahn DB (1997) Estrogen receptor function as revealed by knockout studies: neuroendocrine and behavioral aspects. Horm Behav 31:232-243. CrossRef Medline

Ritter HD, Mueller CR (2014) Expression microarray identifies the unliganded glucocorticoid receptor as a regulator of gene expression in mammary epithelial cells. BMC Cancer 14:275. CrossRef Medline

Safe S, Kim K (2004) Nuclear receptor-mediated transactivation through interaction with Sp proteins. Prog Nucleic Acid Res Mol Biol 77:1-36. CrossRef Medline

Saldanha CJ, Tuerk MJ, Kim YH, Fernandes AO, Arnold AP, Schlinger BA (2000) Distribution and regulation of telencephalic aromatase expression in the zebra finch revealed with a specific antibody. J Comp Neurol 423:619-630. CrossRef Medline

Saldanha CJ, Remage-Healey L, Schlinger BA (2011) Synaptocrine signaling: steroid synthesis and action at the synapse. Endocr Rev 32:532-549. CrossRef Medline

Sato SM, Woolley CS (2016) Acute inhibition of neurosteroid estrogen synthesis suppresses status epilepticus in an animal model. eLife 5:e12917. CrossRef Medline

Schwartz N, Verma A, Bivens CB, Schwartz Z, Boyan BD (2016) Rapid steroid hormone actions via membrane receptors. Biochim Biophys Acta 1863:2289-2298. CrossRef Medline

Seredynski AL, Balthazart J, Christophe VJ, Ball GF, Cornil CA (2013) Neuroestrogens rapidly regulate sexual motivation but not performance. J Neurosci 33:164-174. CrossRef Medline

Seredynski AL, Balthazart J, Ball GF, Cornil CA (2015) Estrogen receptor $\beta$ activation rapidly modulates male sexual motivation through the transactivation of metabotropic glutamate receptor 1a. J Neurosci 35:1311013123. CrossRef Medline

Serey C, Huss B, Chuon T, Ponce L, Sinchak K (2014a) Progesterone receptor, Src kinase, and dopamine D1 receptor signaling pathways in arcuate nucleus converge to facilitate lordosis. In: 45 th Annual American Society for Neurochemistry Meeting, pp PS-11-10, Long Beach, CA.

Serey C, Huss B, Chuon T, Mahavongtrakul M, Sinchak K (2014b) The signaling pathways of progesterone receptor, Src kindase, and dopamine D1 receptor converge in the arcuate nucleus of the hypothalamus to facilitate lordosis. In: Society for Neuroscience, Neuroscience Meeting Planner, Program 167.109, Washington, DC

Shughrue PJ, Lane MV, Merchenthaler I (1997) Regulation of progesterone receptor messenger ribonucleic acid in the rat medial preoptic nucleus by estrogenic and antiestrogenic compounds: an in situ hybridization study. Endocrinology 138:5476-5484. CrossRef Medline

Simerly RB, Carr AM, Zee MC, Lorang D (1996) Ovarian steroid regulation of estrogen and progesterone receptor messenger ribonucleic acid in the anteroventral periventricular nucleus of the rat. J Neuroendocrinol 8:4556. CrossRef Medline

Sinchak K, Wagner EJ (2012) Estradiol signaling in the regulation of reproduction and energy balance. Front Neuroendocrinol 33:342-363. CrossRef Medline

Sinchak K, Mills RH, Tao L, LaPolt P, Lu JK, Micevych P (2003) Estrogen induces de novo progesterone synthesis in astrocytes. Dev Neurosci 25: 343-348. CrossRef Medline

Sinchak K, Maciel M, Thach V, Tea P, Seng H, Serey C, Mahavongtrakul M, Phan J (2014) Estradiol increases colocalization of D1 dopamine receptors and progesterone receptor in the arcuate nucleus of the hypothalamus associated with facilitation of lordosis. In: Society for Neuroscience, Neuroscience Meeting Planner, Program 167.111, Washington, DC

Sinchak K, Dalhousay L, Sanathara N (2015) Orphanin FQ-ORL-1 regulation of reproduction and reproductive behavior in the female. In: Nociceptin opioid- vitamins and hormones (Litwack G, ed), pp 187-221. London: Academic.

Smith JT (2013) Sex steroid regulation of kisspeptin circuits. Adv Exp Med Biol 784:275-295. CrossRef Medline

Stephens SB, Tolson KP, Rouse ML Jr, Poling MC, Hashimoto-Partyka MK, Mellon PL, Kauffman AS (2015) Absent progesterone signaling in kiss- peptin neurons disrupts the LH surge and impairs fertility in female mice. Endocrinology 156:3091-3097. CrossRef Medline

Strehl C, Gaber T, Löwenberg M, Hommes DW, Verhaar AP, Schellmann S, Hahne M, Fangradt M, Wagegg M, Hoff P, Scheffold A, Spies CM, Burmester GR, Buttgereit F (2011) Origin and functional activity of the membrane-bound glucocorticoid receptor. Arthritis Rheum 63:37793788. CrossRef Medline

Swanson CJ, Bures M, Johnson MP, Linden AM, Monn JA, Schoepp DD (2005) Metabotropic glutamate receptors as novel targets for anxiety and stress disorders. Nat Rev Drug Discov 4:131-144. CrossRef Medline

Szego CM, Davis JS (1967) Adenosine 3' $5^{\prime}$-monophosphate in rat uterus: acute elevation by estrogen. Proc Natl Acad Sci U S A 58:1711-1718. CrossRef Medline

Taziaux M, Keller M, Bakker J, Balthazart J (2007) Sexual behavior activity tracks rapid changes in brain estrogen concentrations. J Neurosci 27: 6563-6572. CrossRef Medline

Tremere LA, Jeong JK, Pinaud R (2009) Estradiol shapes auditory processing in the adult brain by regulating inhibitory transmission and plasticity-associated gene expression. J Neurosci 29:5949-5963. CrossRef Medline

Tuscher JJ, Szinte JS, Starrett JR, Krentzel AA, Fortress AM, Remage-Healey L, Frick KM (2016) Inhibition of local estrogen synthesis in the hippocampus impairs hippocampal memory consolidation in ovariectomized female mice. Horm Behav 83:60-67. CrossRef Medline

Ubuka T, Haraguchi S, Tobari Y, Narihiro M, Ishikawa K, Hayashi T, Harada N, Tsutsui K (2014) Hypothalamic inhibition of socio-sexual behaviour by increasing neuroestrogen synthesis. Nat Commun 5:3061. CrossRef Medline

Valadez-Cosmes P, Vázquez-Martínez ER, Cerbón M, Camacho-Arroyo I (2016) Membrane progesterone receptors in reproduction and cancer. Mol Cell Endocrinol 434:166-175. CrossRef Medline

Vasudevan N, Pfaff DW (2007) Membrane initiated actions of estrogens in neuroendocrinology: emerging principles. Endocr Rev 28:1-19. CrossRef Medline

Wang Z, Frederick J, Garabedian MJ (2002) Deciphering the phosphorylation "code" of the glucocorticoid receptor in vivo. J Biol Chem 277: 26573-26580. CrossRef Medline

Webb P, Nguyen P, Valentine C, Lopez GN, Kwok GR, McInerney E, Katzenellenbogen BS, Enmark E, Gustafsson JA, Nilsson S, Kushner PJ (1999) The estrogen receptor enhances AP-1 activity by two distinct mechanisms with different requirements for receptor transactivation functions. Mol Endocrinol 13:1672-1685. CrossRef Medline

Wintermantel TM, Campbell RE, Porteous R, Bock D, Gröne HJ, Todman MG, Korach KS, Greiner E, Pérez CA, Schütz G, Herbison AE (2006) Definition of estrogen receptor pathway critical for estrogen positive feedback to gonadotropin-releasing hormone neurons and fertility. Neuron 52:271-280. CrossRef Medline

Wong AM, Abrams MC, Micevych PE (2015a) $\beta$-Arrestin regulates estradiol membrane-initiated signaling in hypothalamic neurons. PLoS One 10:e0120530. CrossRef Medline

Wong AM, Rudolph LM, Micevych PE (2015b) Estrogen-mediated signaling regulates synaptic proteins in the arcuate nucleus of the hypothalamus. In: Society for Neuroscience, Meeting Planner, Chicago.

Xiao L, Qi A, Chen Y (2005) Cultured embryonic hippocampal neurons deficient in glucocorticoid receptor: a novel model for studying nongenomic effects of glucocorticoid in neural system. Endocrinology 146: 4036-4041. CrossRef Medline

Yang S, Roselli F, Patchev AV, Yu S, Almeida OF (2013) Non-receptortyrosine kinases integrate fast glucocorticoid signaling in hippocampal neurons. J Biol Chem 288:23725-23739. CrossRef Medline

Zhang J, Yang L, Lin N, Pan X, Zhu Y, Chen X (2014) Aging-related changes in RP3V kisspeptin neurons predate the reduced activation of $\mathrm{GnRH}$ neurons during the early reproductive decline in female mice. Neurobiol Aging 35:655-668. CrossRef Medline

Zhou Y, Watters JJ, Dorsa DM (1996) Estrogen rapidly induces the phosphorylation of the cAMP response element binding protein in rat brain. Endocrinology 137:2163-2166. CrossRef Medline

Zuloaga DG, Yahn SL, Pang Y, Quihuis AM, Oyola MG, Reyna A, Thomas P, Handa RJ, Mani SK (2012) Distribution and estrogen regulation of membrane progesterone receptor-beta in the female rat brain. Endocrinology 153:4432-4443. CrossRef Medline 